\author{
Piotr Kostyto* \\ ORCID: 0000-0002-7484-9766 \\ Bydgoszcz
}

\title{
Niewolnicy na drodze do uznania. Józefa Tischnera zmagania $\mathrm{z}$ historiozofią
}

Historia filozofii ma swoje momenta, to jest okresy, w których myśl zrodzona w historycznej konkretności nabiera impetu, stając się globalną i ponadczasową, twierdzi Alain Badiou ${ }^{1}$. Jednym z takich okresów był niemiecki idealizm, trwający od Immanuela Kanta do Georga W. F. Hegla. Okres ten wyznaczył drogi rozwoju filozofii, a także nauk humanistycznych i społecznych na kolejne stulecia. Kiedy Hegel pisał Fenomenologię ducha, zawarł w niej myśl, która okazała się trwalsza niż napoleoński triumf i to wszystko, co nastąpiło po nim. Potężne oddziaływanie wizji heglowskiej ujawniło się także niemal dwa wieki później, gdy Józef Tischner podczas pobytu we Włoszech i Austrii śledził relacje telewizyjne ze strajku w Stoczni Gdańskiej w sierpniu $1980 \mathrm{roku}^{2}$. Sam strajk, podpisanie porozumień gdańskich, ruch Solidarności, dramat stanu wojennego, a następnie tak zwany Okrągły Stół i pierwsze lata funkcjonowania postkomunistycznego państwa były przez

* Dr hab. Piotr Kostyło, prof. UKW, jest kierownikiem Zakładu Filozofii Wychowania i Edukacji Obywatelskiej w Instytucie Pedagogiki Uniwersytetu Kazimierza Wielkiego w Bydgoszczy. Adres: Instytut Pedagogiki UKW, ul. Chodkiewicza 30, 85-064 Bydgoszcz; e-mail: piotr.kostylo@ukw.edu.pl.

${ }^{1}$ Por. Piotr Kostyło, „Alain Badiou o współczesnej filozofii francuskiej”, Kronos 4 (2015): 88.

2 Por. Wojciech Bonowicz, Tischner (Kraków: Znak, 2001), 323-236. 
Tischnera interpretowane w duchu heglowskiej filozofii dziejów, jako walka o uznanie między panami i niewolnikami.

Przyjęcie takiego punktu wyjścia w antropologii filozoficznej i analizach społecznych niosło ze sobą poważne konsekwencje. Najpierw wymagało zgody na taki obraz stosunków międzyludzkich, w których konstytutywnymi zjawiskami stawały się walka o uznanie i towarzyszący jej konflikt, dominacja i podporządkowanie. Dalej konieczne było zaakceptowanie tezy, że napięcia, o których tu mowa, mają swój kres, muszą doprowadzić do ostatecznej syntezy, do stanu, w którym nie będzie już panów i niewolników, ale wszyscy będą uznawani przez wszystkich za takich, jakimi faktycznie są, w duchu wolności i równości. W końcu trzeba było się zgodzić, że stan ten, nazywany zazwyczaj końcem historii, opisywany przez Hegla jako moment pojednania tego, co obiektywne, z tym, co subiektywne, może zostać urzeczywistniony jedynie za sprawą rozwijającego się w historii rozumu. Hegel pisał Fenomenologie ducha w trakcie wojen napoleońskich, Tischner wraz ze studentami czytał i komentował tę książkę zimą na przełomie 1981 i 1982 roku, bezpośrednio po wprowadzeniu w Polsce stanu wojennego ${ }^{3}$. Wojny napoleońskie i upadek komunizmu na trwałe ukształtowały historię świata, jak powiedziałby Hegel, poprzez nie objawił się obiektywny duch dziejów. Rolą filozofa było zrozumienie i wyjaśnienie tego, co się stało.

Józef Tischner pozostawał pod trwałym wpływem myśli Hegla ${ }^{4}$. Z utęsknieniem wypatrywał więc chwili, w której możliwe okaże się wzajemne uznanie panów i niewolników, co w polskim kontekście politycznym i społecznym tamtych czasów oznaczało pojednanie partii komunistycznej i rządzonych przez nią robotników. Komentując Fenomenologię ducha kilka lat po upadku komunizmu, Tischner pisał:

3 Tadeusz Gadacz wspomina: „To był już początek lat 80 . Spotykaliśmy się wtedy przy kościele św. Anny, w sali na parterze, której okna wychodziły na ulicę. Pamiętam taki epizod: na zewnątrz słychać odgłosy walki, huk pocisków z gazem łzawiącym, a my siedzimy i czytamy Fenomenologię ducha Hegla..." [tamże, 381].

4 „Tischner zainteresował się Heglem jeszcze w latach 60., kiedy zajmował się problematyką świadomości. Okres powstania «Solidarności», a następnie stanu wojennego pomógł mu spojrzeć na jego dzieło niejako na nowo” [tamże, 381]; „Jasne jest, że czytając Hegla, sprzyjałem mu - jemu i jego znakomitym komentatorom” [Józef Tischner, Spowiedź rewolucjonisty (Kraków: Znak 1993), 6]; „Z nowożytnych klasyków największy wpływ na kształtowanie się Tischnerowskiego projektu etycznego miała niewątpliwie filozofia Hegla" [Danuta Wajsprych, Pedagogia agatologiczna. Studium hermeneutyczno-krytyczne projektu etycznego Józefa Tischnera (Torun - Olsztyn: Wydawnictwo Naukowe UMK 2011), 85]. 
Wyzwolenie zaczyna się wtedy, gdy w niewolniku budzi się nowa siła - myślenie. Hegel zakończył swe rozważania o panu i niewolniku wprowadzeniem do nowego rozdziału pt. „Rozum”. Pan i niewolnik wzniosą się ponad swe przeciwieństwo, gdy osiągną poziom rozumu. Niewolnictwo i panowanie okażą się wtedy jedną z odmian głupoty 5 .

Czytając teksty Tischnera, można dojść do wniosku, że w Polsce podstawą wzajemnego uznania panów i niewolników mogła stać się najpierw Solidarność i właściwa dla niej etyka osadzona w chrześcijaństwie. Nie doszło jednak do tego, gdyż w 1981 roku partia komunistyczna wykazała się głupotą i odmówiła uznania robotnikom, którzy zasłużyli sobie na nie ciężką pracą, ponoszonymi wyrzeczeniami i mądrą odwagą. Po raz drugi uznanie takie mogło nadejść wraz z umową Okrągłego Stołu, przyjętą przez Tischnera $\mathrm{z}$ wielkimi nadziejami. Wydarzenie to jednak również nie położyło kresu walce między panami i niewolnikami, tym razem dlatego, że głupotą wykazali się robotnicy, niezdolni do życia w wolności i tęskniący za chlebem otrzymywanym wcześniej z rąk panów. Tischner ubolewał nad tym, że wielu niewolników z okresu komunizmu nie rozpoznało czasu swojego nawiedzenia i wciąż ucieka od wolności. „Można sobie przecież wyobrazić, że choć nie ma komunizmu ani komunistów, to są jeszcze klienci komunizmu, którzy przy innym straganie dopominają się o tamte towary"6. Ten typ ludzi Tischner za Aleksandrem Zinowiewem nazwał homo sovieticus.

W obu przypadkach Józefa Tischnera spotkało rozczarowanie. Wzajemne uznanie panów i niewolników nie dokonało się. Żadna ze stron, choć w bardzo różnych kontekstach politycznych i społecznych, nie chciała pozwolić drugiej na bycie taką, jaką tamta rzeczywiście była. Komuniści nie pozwolili robotnikom na skuteczne wyartykułowanie i realizację ich żądań na początku lat osiemdziesiątych, robotnicy zaś nie potrafili być wdzięczni za odzyskaną wolność, nawołując nowe państwo do rewanżu na wczorajszych panach i żądając zaspokojenia bieżących ekonomicznych roszczeń. Tym samym nie nastąpiło pojednanie wolności z rozumem.

Niepowodzenia te były zarazem klęskami pedagogicznymi. Oznaczały one niemożność dojścia przez Polaków do pełnej samoświadomości w procesie wychowawczym realizowanym przez historię. O takiej koncepcji wychowania, rozwijającego się w całości ludzkiego życia, a także w całości

\footnotetext{
5 Tischner, Spowiedź, 42.

6 Józef Tischner, Etyka solidarności. „Homo sovieticus” (Kraków: Znak 2005), 199.
} 
życia ludów i narodów, myślał Hegel. Chociaż filozof niemiecki miał liczne doświadczenia pedagogiczne jako nauczyciel, bardzo rzadko odnosił się do nich w swoich tekstach. Interesowało go przede wszystkim wychowanie jako Bildung, całościowy proces zorientowany nie tyle na nabywanie przez człowieka określonej wiedzy lub umiejętności, ile na świadome formowanie samego siebie.

Fundamentalną kwestią w filozofii Hegla okazuje się Bildung. Termin ten można przethumaczyć jako „wychowanie”, ale można również oddać jego sens, co w wielu kontekstach będzie nawet właściwsze, jako „formację”, „rozwój”, „kulturę”. Dla Hegla termin ten odnosi się do formacyjnego samorozwoju umysłu lub ducha (Geist) - rozwoju rozumianego jako społeczny i historyczny proces. Bildung jest częścią procesu życiowego istoty duchowej: bytu ludzkiego, społeczeństwa, tradycji historycznej. Dokonuje się ono nie przede wszystkim poprzez przekazywanie informacji przez nauczyciela, ale poprzez coś, co Hegel nazywa „doświadczeniem”: procesem rozwijającym się dzięki konfliktowi, w trakcie którego duchowy byt odkrywa swoją własną tożsamość lub indywidualność, i tak długo jak stara się on zaktualizować tę indywidualność, trwa on w procesie odkrywania ${ }^{7}$.

W wielu punktach koncepcja Bildung jest zbieżna $\mathrm{z}$ teologicznymi koncepcjami wychowania. Dostrzegał to z pewnością Józef Tischner, który jako duchowny i nauczyciel przyszłych księży był osadzony w chrześcijańskim nurcie edukacji, odgrywając rolę raczej formatora charakterów i sumień niż nauczyciela we współczesnym tego słowa znaczeniu. W formacji chrześcijańskiej, podobnie jak w przypadku Bildung, chodzi nie tyle o przekazywanie określonej puli wiedzy, ile o ukształtowanie pełnej osobowości wychowanka. W obu przypadkach trzeba mówić raczej o ciągłym procesie niż o określonym etapie życia, mającym swój początek i koniec. Podobną orientację prezentuje także współczesna pedagogika religii.

W pedagogice powraca pytanie o cele wychowania i tym samym o cel ludzkiego życia. Pojawia się idea „humanizacji wychowania”, a więc akcentuje się ludzkie wartości, zarysowuje się odwołanie do klasycznej paidei zmierzającej do „budowania człowieczeństwa w człowieku”, zaczyna się mówić i bronić

7 Allen W. Wood, „Hegel on Education”, w: Philosophy as Education. New Historical Perspectives, red. Amélie O. Rorty (London: Routledge, 1998), 301. 
podmiotowości człowieka, podstawowych wartości w wychowaniu: prawdy, dobra i piękna, duchowości człowieka ${ }^{8}$.

Zbieżność koncepcji heglowskich z koncepcjami religijnymi, czy to w obszarze pedagogii, czy w innych obszarach kultury, nie była przypadkowa. Hegel w swojej historiozofii zaproponował pewien typ racjonalizacji chrześcijaństwa, który w wielu punktach przypomina religię. Dla Józefa Tischnera podobieństwa między obiema koncepcjami były pociągające intelektualnie, ale jak się wydaje, okazały się też zwodnicze. Uwikłały bowiem krakowskiego filozofa w głębokie zmagania $\mathrm{z}$ historiozofią, w bolesne próby uzgodnienia sensu ducha obiektywnego z sensem Ducha Świętego, ostatecznie zaś - rozumu z wiarą. Droga dochodzenia do wolności w idealistycznej filozofii niemieckiej i chrześcijaństwie nie jest taka sama, nawet jeśli pod wieloma względami jest ona podobnie opisywana. Warto w tym punkcie zadać pytanie, czy zbieżność heglowskiej filozofii dziejów z biblijną historią zbawienia była pomocą czy raczej przeszkodą dla Józefa Tischnera w jego analizach zastanej sytuacji społecznej w Polsce oraz przewidywaniach kierunków, w których sytuacja ta powinna się rozwinąć. Pytanie to stanie się nicią przewodnią prowadzonych dalej analiz.

Heglowska filozofia dziejów otwiera możliwości różnych interpretacji, niekiedy sprzecznych. W tekstach Józefa Tischnera można znaleźć wyraźne odniesienia do trzech interpretacji, które częściowo są komplementarne, częściowo zaś wykluczają się nawzajem. Autorami tych interpretacji byli kolejno Karol Marks, Alexandre Kojève oraz sam Józef Tischner. Wszystkie interpretacje dotyczą dróg dochodzenia do wzajemnego uznania między panami i niewolnikami, twórczego przezwyciężania niszczących ich konfliktów. Marks uważał, że uznanie takie stanie się możliwe dopiero wówczas, gdy ostatecznie zostanie zniesiony podział na panów i niewolników, to zaś nastąpić może tylko w wyniku rewolucji. Rolą rewolucji jest ostateczne zniszczenie klasy panów i oddanie władzy w ręce robotników. Kojève w swoich komentarzach do Fenomenologii ducha nie podzielał radykalnych przewidywań Marksa, co było zrozumiałe, gdyż sam widział, że nie speł-

${ }^{8}$ Zofia J. Zdybicka, Religia w kulturze. Studium z filozofii religii (Lublin: Polskie Towarzystwo Tomasza z Akwinu, 2010), 149. Na ten temat również: Katarzyna Olbrycht, Prawda, dobro i piękno w wychowaniu człowieka jako osoby (Katowice: Wydawnictwo Uniwersytetu Śląskiego, 2000); Zdzisław Pawlak, „Rola religii w wychowaniu człowieka. Aspekt filozoficzno-teologiczny", w: Edukacyjny potencjat religii, red. Jerzy Bagrowicz, Jarosław Horowski (Toruń: Wydawnictwo Naukowe UMK, 2012), 105-119. 
niają się one w życiu społecznym, niezależnie od tego, gdzie ideologia komunistyczna zdobywała panowanie. Uważał natomiast, że pojednanie między panami i niewolnikami będzie mogło się urzeczywistnić dzięki twórczej i uczciwej pracy tych drugich, która zostanie w końcu doceniona przez tych pierwszych. Wreszcie Tischner, choć sam wyraźnie podążał tropem Kojève’a, zaproponował własne rozstrzygnięcie. Uznał, że najpewniejszym środkiem przezwyciężenia konfliktu między panami i niewolnikami będzie chrześcijańska solidarność oparta na miłosierdziu. Typem bohatera, który miał pokazać, na czym polega w praktyce pojednanie między niewolnikami i panami, stał się dla Tischnera miłosierny Samarytanin, biorący na swoje barki odpowiedzialność za życie pobitego Żyda, swojego wczorajszego nieprzyjaciela.

Przypatrzmy się tym trzem tropom: wyzwoleniu poprzez rewolucję, wyzwoleniu poprzez pracę oraz wyzwoleniu poprzez solidarność. Każdy z tych tropów zostanie wzbogacony konkretną filozofią edukacji.

\section{Wyzwolenie poprzez rewolucję}

Karol Marks uważał, że filozofia Georga W. F. Hegla stoi na głowie i trzeba ją przestawić na nogi. Miało to się stać poprzez uświadomienie sobie, że to nie idee kształtują stosunki społeczne, jak chciał Hegel, ale odwrotnie, stosunki społeczne są pierwotne wobec idei i to one je kształtują. Postulat ten znalazł wyraz w słynnym powiedzeniu Marksa, że ,[n]ie świadomość ludzi określa ich byt, lecz przeciwnie, ich społeczny byt określa ich świadomość" ". Józef Tischner był przeciwny tej tezie, ale sprzeciw ten nie wynikał wprost z chęci obrony filozofii Hegla, ale z prostej wiary religijnej, wedle której materialny świat został stworzony przez osobowego i duchowego Boga. Marksiści nie wierzyli w Boga, co więcej, uważali, że wiara religijna przyczynia się do utrzymywania niesprawiedliwości i cierpienia na świecie i osłabia dążenia niewolników do poprawy ich sytuacji. Warunkiem tej poprawy było według Marksa i jego następców ostateczne rozprawienie się z religią i stojącymi na jej straży panami.

Lektura dzieł Hegla musiała nieść dla Tischnera sugestię zbieżności romantycznego, niemieckiego idealizmu z chrześcijaństwem. Zbieżność ta

9 Por. Karol Marks, „Przyczynek do krytyki ekonomii politycznej”, tłum. Edward Lipiński, https://maopd.files.wordpress.com/2012/02/przyczynek-do-krytyki-ekonomii-politycznej-1859.pdf [dostęp: 15.04.2018]. 
była często podnoszona przez samego Tischnera i jego uczniów ${ }^{10}$. W tym sensie powrót do Hegla mógł być rozumiany jako sprzeciw wobec marksizmu, powrót do źródeł i namysł nad tym, w jaki inny sposób, różny od marksistowskiego, można by rozwinąc tę filozofię, aby wyjaśniła ona to, co działo się wówczas w Polsce i Europie. Było to przedsięwzięcie interesujące poznawczo, ale też odważne, biorąc pod uwagę, że filozofia, jaką w tamtym czasie uprawiano w środowisku katolickim, zwłaszcza w seminariach duchownych, była zdystansowana wobec heglowskiego idealizmu, a niekiedy otwarcie wroga wobec niego ${ }^{11}$. Józef Tischner wszedł w tradycję heglowską i trwał przy niej konsekwentnie do końca. Była ona dla niego użyteczna nie tylko ze względu na spory z marksizmem, ale także jako wyraźny drogowskaz w rozwijaniu jego własnej, oryginalnej filozofii dramatu, w której kluczową rolę odgrywały pojęcia upływającego czasu, zmiany i samorozumienia.

Wróćmy jednak do marksistowskich interpretacji filozofii Hegla. Marks uważał, że tylko rewolucja proletariacka jest w stanie skutecznie znieść napięcie między panami, czyli burżuazją, a niewolnikami, czyli robotnikami. Postulat ten w latach siedemdziesiątych i osiemdziesiątych XX wieku miał szczególną wymowę w Polsce i innych krajach Europy Środkowej i Wschodniej. Wynikało to stąd, że nie można było wówczas podchodzić do niego tylko jako do ideologicznego wezwania, ale trzeba było się zmierzyć z praktyką społeczną, co więcej, z kulturą, która z tego wezwania wyrosła w wielu państwach. Każdy, kto w tamtym okresie wchodził w dyskusję intelektualną z marksizmem, musiał uwzględnić ów praktyczny wymiar komunistycznej ideologii. Lektura licznych tekstów Józefa Tischnera sprzed okresu pierwszej Solidarności, a potem całego jego społecznie zorientowanego dorobku z tego okresu i z lat bezpośrednio po nim, pokazuje, że krytyka marksizmu

${ }^{10}$ Na przykład Tadeusz Gadacz w swoich wykładach z filozofii nowożytnej, prowadzonych w roku akademickim 1989-1990 na Papieskiej Akademii Teologicznej, wskazywał na wątki religijne i teologiczne w filozofii Hegla. Podkreślał inspirację Hegla takimi pojęciami jak „Trójca Święta”, „stworzenie świata”, „mesjanizm” czy „opatrzność” (rękopis wykładów w posiadaniu autora).

${ }^{11}$ Przykładem niechętnego stanowiska wobec heglowskiego idealizmu może być poniższa wypowiedź: „Jeśli filozofia ma tłumaczyć rzeczywistość w świetle ostatecznych, najgłębszych uzasadnień, to musi zacząć swoje dociekania od tej rzeczywistości. Dlatego też wydają się podejrzane te systemy filozoficzne, które w badaniach i analizie wychodziły od pewnych założeń - dogmatów apriorystycznych, niesprawdzonych (np. Spinoza z substancji, Fichte z czystego «ja», Schelling z Absolutu, Hegel z idei” [Mieczysław A. Krąpiec, Realizm ludzkiego poznania (Poznań: Pallottinum, 1959), 115]. 
była rozwijana przez krakowskiego myśliciela dwutorowo - przez nawiązania do tekstów marksistów oraz przez odniesienia do aktualnej wówczas praktyki społecznej.

Przewaga Józefa Tischnera nad wieloma katolickimi intelektualistami z Europy i spoza niej, zafascynowanymi marksizmem i możliwościami jego społecznych i kulturowych aplikacji, w tym w sferze religii, polegała na tym, że znał on marksizm w jego wymiarze praktycznym, codziennym, i widział, do czego doprowadził całe narody w tej części Europy ${ }^{12}$. Tischner widział przede wszystkim to, że nie spełniła się główna zapowiedź marksistów, to jest przezwyciężenie konfliktu między panami i niewolnikami. Rewolucja, która doprowadziła do pozbawienia panów władzy i majątków, a często także życia, nie zagwarantowała powszechnego uznania wszystkich przez wszystkich. Przeciwnie, na zgliszczach obalonego systemu powstały nowe nierówności i nowe konflikty, tym razem między członkami kierownictwa partii robotniczej a robotnikami, których partia ta rzekomo reprezentowała. Konflikty te były permanentne, niekiedy okazywały się krwawe. Józef Tischner, krytycznie nastawiony do marksizmu, zdawał sobie sprawę z tego napięcia, niemniej przez długi czas uważał, że jest ono nie do uniknięcia. Władza komunistyczna jawiła się jako niemożliwa do zachwiania, zatem robotnikom pozostawało jedynie trwanie w biernym oporze. Przekonanie o konieczności współistnienia marksistowskiej władzy i niechętnej jej większości społeczeństwa skłoniło Tischnera do poszukiwania dróg dialogu między obiema stronami.

Dialog ten nie był łatwy, gdyż Józef Tischner odrzucał komunizm nie tylko z powodów filozoficznych. Jego sprzeciw wobec tej ideologii miał o wiele głębsze źródła. Wynikał ze światopoglądu krakowskiego filozofa, a zwłaszcza jego religijności i przywiązania do Kościoła, które w zasadniczy sposób kształtowały jego tożsamość. W 1989 roku Tischner pytał, „[c]zym stał się komunizm dla Kościoła?”. I odpowiadał:

Odpowiedź, jaką proponuję, może w pierwszej chwili budzić sprzeciw, spróbuję jednak ją usprawiedliwić. Otóż komunizm był dla Kościoła nie tylko - jak dla wielu innych mieszkańców Polski - atakiem na własność prywatną, rozgrzeszeniem przemocy rewolucyjnej, nosicielem ateizmu i materializmu, czy

12 Związki katolicyzmu z marksizmem w Europie były szczególnie silne we Francji i we Włoszech. Wynikały one z aktywności partii komunistycznych w tych krajach w środowiskach robotniczych. Por. John Hellman, „French 'Left-Catholics' and Communism in the Nineteen-Thirties”, Church History 12 (1976): 507-523. 
zapowiedzią wspaniałej przyszłości świata, był przede wszystkim kolejną falą neopogaństwa, jaka napłynęła w sam środek chrześcijańskiej Europy ${ }^{13}$.

Odrzucenie komunizmu miało jednak dla Józefa Tischnera także wymiar filozoficzny. Karol Marks, pisząc o ostatecznym przezwyciężeniu konfliktu między panami i niewolnikami, zakładał, że warunkiem postrewolucyjnego pojednania wszystkich ze wszystkimi musi się stać odrzucenie religii. Religia była dla Marksa narzędziem ciemiężenia proletariuszy przez kapitalistów, to dzięki niej panowie mogli utrzymywać niewolników w stanie zależności, skutecznie ich przekonując, że stan taki jest pożądany przez Boga i jakiekolwiek próby zmienienia go będą poczytywane przez Boga jako akty nieposłuszeństwa. Tischner nie mógł się zgodzić z tą interpretacją. Nie tylko jako człowiek wierzący, ale także jako filozof biorący na poważnie postulat wolności. Czy możliwa była wolność niewolników w sytuacji, gdy koniecznym warunkiem tej wolności stawało się wyrzeczenie wiary religijnej? W przekonaniu Tischnera, niezależnie od tego, jak ludzie praktykują swoją wiarę, nawet gdy czynią to naiwnie i niemądrze, muszą mieć do niej pełne prawo $^{14}$.

Ponieważ dotychczasowe obietnice przezwyciężenia napięć klasowych poprzez rewolucję proletariacką, nacjonalizację własności prywatnej i poddanie całej gospodarki reżimowi ciągłego planowania nie zostały przez komunistów spełnione ani w Polsce, ani w innych krajach, Józef Tischner był przekonany, że każda kolejna marksistowska próba wyzwolenia niewolników zakończy się katastrofą. To przekonanie kazało mu odnosić się z dużym dystansem do prób łączenia marksizmu z chrześcijaństwem, charakterystycznych w tamtym okresie między innymi dla teologii wyzwolenia.

Krakowski filozof mówił o tym na kolokwium w Caracas w 1989 roku $^{15}$. Przeciwstawił tam teologię wyzwolenia etyce solidarności. Zauważał, że tym, co odróżnia teologię wyzwolenia od etyki solidarności, są dwie rzeczy: stosunek do rewolucji oraz stosunek do etyki. Według niego, podczas gdy teologia wyzwolenia dąży do rewolucji, Solidarność jako ruch społeczny szuka dróg przezwyciężenia skutków rewolucji. Jeśli chodzi o etykę, to zdaniem Tischnera teologia wyzwolenia chce ją przekształcić w taki spo-

13 Józef Tischner, Filozofia współczesna (Kraków: Instytut Teologiczny Księży Misjonarzy, 1989), 243.

${ }^{14}$ Por. Sławomir Przybyło, „Wolność według Lorda Actona i Józefa Tischnera. Analiza porównawcza myśli dwóch katolickich liberałów", Politeia 11 (2014): 359-385.

${ }^{15}$ Por. Tischner, Etyka solidarności, 214-230. 
sób, aby otwierała drogę rewolucji, natomiast Solidarność chce zaszczepić etykę w świecie postrewolucyjnym. „Państwo, które trzeba zreformować, jest wynikiem rewolucji" ${ }^{16}$. Jest interesujące, że omawiając funkcjonowanie państwa, w którym dokonała się już rewolucja, Tischner nie skupił się na nacjonalizacji i ateizmie, ale na degradacji pracy. Przekonywał, że w ruchu Solidarności nie chodziło w pierwszej kolejności o przezwyciężenie ubóstwa, ale o uzdrowienie pracy. Komuniści zniszczyli bowiem pracę, zniszczyli jej etos, i to okazało się największym problemem Polski. Źródłem kryzysu marksizmu w naszej części Europy, tłumaczył Tischner, jest „klęska zaproponowanego systemu pracy"17. Praca została uspołeczniona i ta zmiana okazała się dla pracy śmiertelna. Nie chodzi więc o to, że w komunizmie byli staliniści i inni oprawcy, ale o to, że komunizm zniszczył pracę. Wyzwolenie zapowiadane przez rewolucjonistów nie nadeszło, w zamian za to niewolnicy wpadli w jeszcze głębszą niewolę. Wcześniej byli ludźmi ubogimi, zmuszonymi do sprzedaży swojej pracy znacznie poniżej jej wartości. Później stali się proletariuszami, którzy pracując dla państwa, utracili nawet tę niewielką cząstkę swojej pracy, nad którą wcześniej sprawowali kontrolę.

Dopóki reżim komunistyczny wydawał się trwały, Józef Tischner zainteresowany był przede wszystkim kwestią współistnienia marksistowskiej władzy i opozycyjnej wobec niej większości społeczeństwa. Pytaniem wówczas było nie to, w jaki sposób wyzwolić się całkowicie spod władzy komunistów, ale to, jak żyć obok nich i z nimi, zachowując tyle wolności, ile można było zachować. Tischner uważał, że jest możliwe dzięki dialogowi.

Chrześcijanie zobaczyli, że socjalizmu w Polsce pozbyć się nie można. Marksiści zobaczyli, że nie można również pozbyć się chrześcijaństwa. Jesteśmy skazani na sąsiedztwo w granicach jednego i tego samego kraju. Co stąd wynika? Spróbuję spojrzeć na rzecz oczami marksisty, który nie kocha religii, i oczami chrześcijanina, który nie kocha marksizmu ${ }^{18}$.

Książka Polski kształt dialogu jest krytyką myśli marksistowskiej z punktu widzenia chrześcijaństwa personalistycznego. Rdzeniem tej krytyki jest spór o człowieka. Czy człowiek jest autonomiczny, odpowiadający za swoje wybory przede wszystkim przed swoim Stwórcą, czy też jest wytworem stosunków społecznych, w których wzrastał, i jego wybory są w istocie wy-

\footnotetext{
16 Tamże, 221.

17 Tamże, 224.

18 Józef Tischner, Polski kształt dialogu (Kraków: Znak, 2002), 10.
} 
borami klasy społecznej, do której przynależy? O tym przede wszystkim pisał Józef Tischner, broniąc koncepcji autonomii człowieka. Jego ówczesna wrażliwość intelektualna nie była jednak dogmatyczna. Chciał rozmawiać z komunistami, którzy w perspektywie heglowskiej historiozofii wciąż byli panami. Potrzeba dialogu wynikała nie tylko z codziennej współpracy państwa i Kościoła, ale także z personalistycznej tradycji rozwijanej wówczas w środowisku krakowskiej inteligencji katolickiej. Tischner był wierny postawie dialogu nawet wówczas, gdy jak sam pisał, marksiści konsekwentnie odmawiali podejmowania rozmów ze społeczeństwem. „Patrzę raz jeszcze na dzieje naszego dialogu. Pytam: był dialog czy go nie było? Niestety, według mego przekonania dialogu nie było. Sytuacja chrześcijaństwa przypominała sytuację Sokratesa w więzieniu"19. Pozostał jej wierny także wtedy, gdy zmieniła się sytuacja społeczna i polityczna, w wyniku czego partia komunistyczna utraciła władzę i w pewnym sensie z pozycji panów spadła na pozycję niewolników ${ }^{20}$.

Bardzo interesującym tropem w pedagogicznych analizach myśli Józefa Tischnera, w kontekście jego sporów z marksizmem o istotę wyzwolenia, byłoby porównanie koncepcji krakowskiego filozofa $\mathrm{z}$ rozważaniami brazylijskiego pedagoga Paula Freirego. Na temat pedagogicznych poglądów Freirego napisano już sporo w polskiej pedagogice, także na łamach Paedagogia Christiana ${ }^{21}$. W swojej najbardziej znanej pracy, Pedagogy of the Oppressed, Freire podejmuje temat wyzwolenia ludzi uciśnionych w Brazylii w kontekście postkolonializmu ${ }^{22}$. Warunkiem wyzwolenia, według Freirego, jest obudzenie świadomości i sumień ludzi uciśnionych. Jest to możliwe dzięki programom alfabetyzacyjnym realizowanym na rzecz najuboższych przez lewicowych przywódców. Freire dostrzegał ogromny potencjał filozofii i pedagogiki marksistowskiej jako narzędzi rozumienia i przemiany społeczeństwa. Był też pozytywnie zorientowany na rewolucję, jako jedyny według niego sposób wyjścia z niewoli. Rewolucję muszą przeprowadzić niewolnicy nie tylko ze względu na siebie, ale też ze względu na panów.

19 Tamże, 13.

20 Tym, co niepokoiło Tischnera po 1989 roku, były postawy rewanżyzmu, chęci odwetu ze strony wczorajszych niewolników na wczorajszych panach. Przed taką postawą przestrzegał m.in. w tekście „Rewolucja i wstyd” w zbiorze Etyka solidarności. Homo sovieticus.

${ }^{21}$ Por. Hanna Kostyło, „Refleksja jako podstawa podmiotowości. Według antropologii Paula Freirego", Paedagogia Christiana 2 (2017): 157-170. W bibliografii do przytoczonego artykułu wskazano wiele innych tekstów na ten temat.

22 Por. Paulo Freire, Pedagogy of the Oppressed (New York-London: Continuum 2005). Publikacja z 2005 roku ukazała się w 30 rocznicę ukazania się pierwszego wydania książki. 
Takie jest zatem wielkie humanistyczne i historyczne zadanie uciśnionych: wyzwolenie siebie oraz własnych ciemiężców. Ciemiężcy, którzy stosują opresję, eksploatują oraz gwałcą, korzystając z posiadanej przez siebie władzy, nie potrafią znaleźć w tej władzy siły do wyzwolenia, czy to uciśnionych, czy siebie ${ }^{23}$.

Rewolucja jest według Freirego jedynym sposobem dojścia do wolności, konieczną ceną, którą musi zapłacić społeczeństwo za przezwyciężenie napięcia między niewolnikami a panami. $Z$ tym założeniem Józef Tischner zasadniczo się nie zgadzał ${ }^{24}$. W odróżnieniu od Freirego uważał, że zmiany społeczne oparte na przemocy są nieetyczne i z gruntu sprzeczne z literą oraz duchem chrześcijaństwa.

\section{Wyzwolenie poprzez pracę}

Józef Tischner odradzał studentom lekturę Fenomenologii ducha, wskazując, że tekst Hegla sam w sobie jest niejasny i umożliwia sprzeczne interpretacje, zachęcał natomiast do sięgnięcia po komentarze do tekstu autorstwa Alexandra Kojève'a, które uznawał za „szczególnie przydatne”25. W swoich analizach myśli Hegla Tischner korzystał również z komentarzy Jeana Hyppolite'a ${ }^{26}$. Kojève, rosyjski imigrant, interpretował myśl niemiec-

23 Tamże, 45.

${ }^{24}$ Jako interesujący przykład dialektycznego pojmowania ówczesnych wydarzeń może posłużyć książka Georga Weigela, Ostateczna rewolucja. Kościót sprzeciwu a upadek komunizmu, tłum. Wojciech Buchner (Poznań: W Drodze, 1995). Tischner sprzeciwiał się rewolucji opartej na przemocy, zabiegał natomiast o rewolucję etyczną w Polsce, tj. o obudzenie sumień niewolników i panów. Słowo „rewolucja” zmieniało tym samym swoje znaczenie, stawało się innym pojęciem. O budzeniu sumień pisał także Freire, optując wszakże za marksistowską wersją rewolucji.

${ }_{25}$ Takie przekonanie wyrażał Tischner m.in. na wykładach z filozofii człowieka, wygłaszanych na Papieskiej Akademii Teologicznej w Krakowie w roku akademickim 1989/1990 (rękopis wykładów jest w posiadaniu autora). Tischner uważał Kojève’a za jednego „ze znakomitych znawców myśli heglowskiej” [por. Józef Tischner, Etyka a historia. Wyktady (Kraków: Instytut Myśli Józefa Tischnera, 2008), 4; Alexandre Kojève, Wstęp do wykładów o Heglu, tłum. Światosław F. Nowicki (Warszawa: Fundacja Aletheia, 1999), 4]. O roli Kojève'a w powojennej myśli francuskiej zobacz: Marek Kwiek, Dylematy tożsamości. Wokót autowizerunku filozofa w powojennej myśli francuskiej (Poznań: Wydawnictwo Naukowe Instytutu Filozofii UAM, 1999).

${ }^{26}$ Chodzi tu o pracę: Jean Hyppolite, Genèse et Structure de la «Phénoménologie de l'Esprit» de Hegel (Paris: Aubier, 1946). Podejścia Kojève'a i Hyppolite'a do myśli Hegla 
kiego idealisty z perspektywy późniejszych filozofów, Karola Marksa i Martina Heideggera.

Kojève wychodzi od idei uniwersalnego, historycznego procesu oraz pojednania zorientowanego na jedność, a następnie dokonuje syntezy tych idei $\mathrm{z}$ teoriami Marksa i Heideggera. Przejmuje marksistowską filozofię produkcji, która sytuuje transformatywną aktywność bytu kierującego się pożądaniem w samym centrum historycznego procesu, zakorzeniając ją w warunkach materialnego postępu i ideologicznej walki. Odnosząc się do Heideggera, Kojève także definiuje ten byt jako wolny, ,negatywny” i radykalnie czasowy, uznając i ,wykorzystując” w ten sposób jego śmiertelność, uwalniając go od determinizmu i metafizycznej iluzji, pozwalając mu tworzyć jego własną rzeczywistość poprzez samo doświadczenie ${ }^{27}$.

Kojève wyjaśniał Hegla w sposób oryginalny i odważny, skupiając się na kluczowej roli pracy, która umożliwia niewolnikom stopniowe wychodzenie ze stanu zależności od panów i uzyskiwanie ich uznania ${ }^{28}$. Niewolnicy, w odróżnieniu od panów, nie są gotowi, by w walce o uznanie postawić na szali swoje życie. W tym sensie przegrywają tę walkę. Nie poddają się jednak i kierują swoje wysiłki na przekształcanie świata, w którym żyją. Tworzą dobra i oferują usługi, z których korzystają także panowie. Poprzez pracę budują świat dla siebie i dla panów. Wizja wyzwalającej mocy pracy rozwinięta przez Kojève'a była tym, czego potrzebował Tischner, gdy zastanawiał się nad upadkiem pracy w komunizmie. Ponawiane apele Tischnera o pracę nad pracą wynikały z przekonania, że odnowa ludzkiej pracy jest niezbędna, aby wyjść z matni tragicznego, marksistowskiego eksperymentu ${ }^{29}$.

różnią się. Podczas gdy pierwszy z myślicieli znacząco zmodyfikował interpretację heglowskiej filozofii historii, drugi pozostawał wierny tradycyjnemu jej rozumieniu [Por. też Tischner, Spowiedź, 15].

${ }^{27}$ „Alexandre Kojève”, w: Internet Encyclopedia of Philosophy, http://www.iep.utm. edu/kojeve/ [dostęp: 20.04.2018].

${ }^{28}$ Prace nad tłumaczeniem Wstępu do wykładów o Heglu rozpoczęły się w kręgu uczniów Józefa Tischnera na początku lat osiemdziesiątych. Efektem tych prac była książka Alexandre Kojève, Łączny komentarz do pierwszych sześciu rozdziatów „,Fenomenologii ducha”, thum. Tadeusz Gadacz (Kraków: Wydział Filozofii PAT, 1982).

${ }^{29}$ Zdanie: „Została nam zadana praca nad pracą” wypowiedział w 1987 roku papież Jan Paweł II w trakcie swojej pielgrzymki do Polski. Podczas swoich wcześniejszych wizyt w Polsce Jan Paweł II mówił o ,pracy nad kapitałem”. Roman Graczyk zauważa, że „,[t]o, co Tischner pisał wtedy o pracy, współbrzmiało ze słynną formułą Jana Pawła II «praca 
Alexandre Kojève był pod znaczącym wpływem filozofii Marksa, ale przejmował z niej jedynie pewne wątki. Najważniejszym z nich był wspomniany wątek pracy, interpretowany w duchu Marksa jako wyraz konfliktu między panami i niewolnikami. Niemniej w odróżnieniu od Marksa Kojève uważał, że konflikt ten nie musi doprowadzić do rewolucji, że można go stopniowo załagodzić, pokazując panom rzeczywistą wartość pracy niewolników. $\mathrm{W}$ ten sposób, zamiast unicestwienia panów przez niewolników, możliwe okaże się uznanie niewolników przez panów. Taka interpretacja dobrze wpisywała się w filozofię państwa kapitalistycznego, w której najpewniejszym gwarantem pojednania między burżuazją a robotnikami był pełen dostęp do dóbr i usług przez jednych i drugich. Kojève zainspirował swoimi komentarzami do Hegla takich dwudziestowiecznych, konserwatywnych myślicieli amerykańskich jak Leo Strauss ${ }^{30}$, Alan Bloom ${ }^{31}$ oraz Francis Fukuyama ${ }^{32}$. Wydaje się, że analogiczny wpływ wywarł także na Józefa Tischnera. Tym, co było szczególnie interesujące dla Tischnera w myśleniu Kojève’a, był wspomniany wątek pracy jako wyzwolenia. Kojève podkreślał, że praca niewolnika dla pana nie była $\mathrm{w}$ istocie przekleństwem tego pierwszego, lecz szansą na wyzwolenie. Bowiem to nie panowie, ale niewolnicy okazują się prawdziwymi twórcami kultury. Przez swój wysiłek zmagania się z materią niewolnicy coraz wyraźniej uświadamiają sobie, że tworzą bezpieczne i dostatnie życie zarówno dla panów, jak i dla siebie. Praca staje się w ten sposób szczególnie ważnym elementem kultury, przemienia świat materialny, ale również świadomość pracujących niewolników. Niewolnicy dochodzą do swojego wyzwolenia nie dzięki panom, ale dzięki sobie. Pierwszym krokiem na tej drodze jest zapanowanie za pośrednictwem pracy nad światem materialnym. Ale żeby mogło się to dokonać, praca niewolników musi być

przed kapitałem» - zawartą w encyklice Laborem exercens (1981 r.) i powtórzoną podczas spotkania z robotnikami w Katowicach w czerwcu 1983 r.” [„Tischner, Józef. Ksiądz na manowcach", http://krakow.wyborcza.pl/krakow/1,35802,122149.html?disableRedirects=true, (dostęp: 20.04.2018)].

${ }^{30}$ Por. Leo Strauss, O tyranii: zawiera korespondencje Strauss-Kojève, red. Victor Gourevitch, Michael S. Roth, tłum. Paweł Armada, Arkadiusz Górnisiewicz (Kraków: Wydawnictwo Uniwersytetu Jagiellońskiego, 2009).

${ }^{31}$ Por. Alexandre Kojève, Introduction to the Reading of Hegel. Lectures on the „Phenomenology of Spirit" (Ithaca-London: Cornell University Press, 1969). Redaktorem naukowym tej publikacji był Allan Bloom.

32 Por. Francis Fukuyama, Koniec historii, tłum. Tomasz Bieroń, Marek Wichrowski (Poznań: Wydawnictwo Zysk i S-ka, 1992). Allan Bloom był profesorem i mentorem Francisa Fukuyamy. 
uzdrowiona $\mathrm{z}$ choroby uspołecznienia. Apele Tischnera o takie uzdrowienie pracy, wygłaszane konsekwentnie w latach osiemdziesiątych i dziewięćdziesiątych, nie miały na celu zreformowania marksistowskiej filozofii pracy, ale przygotowanie robotników do pracy w nowych warunkach gospodarczych. Brzmiały one jak ostrzeżenie: jeśli chcecie być wolni, musicie nauczyć się inaczej pracować.

Uwypuklenie przez Kojève'a wątków związanych z pracą w myśli Hegla zainspirowało Tischnera do postawienia, a następnie rozwijania tezy, że poprzez pracę niewolnik stopniowo dochodzi do wolności, a tym samym do uznania ze strony panów. Ostateczne pojednanie wolności z rozumem byłoby więc możliwe dzięki rozumnej pracy i dokonywałoby się w kontekście współczesnego państwa liberalno-demokratycznego. Tischner bardzo liczył na taki właśnie rozwój wypadków, podobnie jak trzech wymienionych amerykańskich konserwatystów, dostrzegał ogromny potencjał w wolnym rynku i konkurencji jako instrumentach dochodzenia wczorajszych niewolników do uznania.

Ale niewolnik jest bytem dialektycznym. W tym samym czasie, gdy pracuje na rzecz swojej wolności, wyciąga rękę w stronę pana, oczekując od niego chleba. Droga do wolności przeplata się z akceptacją zniewolenia. W pracy ukryty jest potencjał wolności, niemniej sama praca nieustannie przypomina o zniewoleniu, zależności, podporządkowaniu. Niewolnik pracuje bowiem nie dla siebie, ale dla pana. Dzieje się tak dlatego, że w pewnym momencie nie było go stać na postawienie na szali swojego życia, zaryzykowanie własnej śmierci w owej walce o uznanie, która według Hegla jest niezbędna, aby dojść do odpowiedzi na pytanie, kim się jest. Niewolnika nie było na to stać, więc teraz musi trudzić się, aby stwarzać świat dla pana, świat historyczny i kulturowy, w którym pan może doświadczać uznania i potwierdzać swoje panowanie.

Skupmy się na świadomości niewolnika. Co Kojève o niej pisze? Niewolnik egzystuje w sposób czysto naturalny, biologiczny, nie ma w nim negatywności (nie jest gotowy na postawienie na szali swojego życia w walce o uznanie, jego pożądania są naturalne). „Niewolnik woli bowiem żyć (jako niewolnik) niż umrzeć (w imię wolności). W rezultacie jest zależny od życia organicznego; woli właśnie życie organiczne; jest tym życiem" ${ }^{33}$. Niewolnik uznaje Pana, uznając jego prawo do własności i posiadania. Kojève zauważa, że „Pan nie jest prawdziwym człowiekiem - jest to tylko pewien etap. Jest to nawet impas: nigdy nie będzie on «usatysfakcjonowany» (befriedigt)

33 Kojève, Wstęp, 86. 
uznaniem, które jest jego udziałem, ponieważ uznają go tylko Niewolnicy"34. Prawdziwym człowiekiem może się stać natomiast Niewolnik. „To Niewolnik stanie się człowiekiem historycznym, człowiekiem prawdziwym: koniec końców - Filozofem, Heglem, który zrozumie, dlaczego i jak to się dzieje, że ostateczną satysfakcję osiąga się dzięki uznaniu wzajemnemu" "35. $\mathrm{Tu}$ pojawia się pozytywny opis niewolnika. Kojève kładzie akcent na pracę niewolnika. Praca ta ma wymiar negatywny, to znaczy podporządkowuje niewolnika panu, ale ma również wymiar pozytywny, umożliwia bowiem przeobrażenie świata. To niewolnik, a nie pan, przez pracę dokonuje przeobrażenia przyrody. Kojève wskazuje, że to niewolnik, nie pan, ma w sobie potencjał, aby stać się prawdziwym człowiekiem. Jest to możliwe dzięki pracy, którą wykonuje na rzecz pana. Praca przemienia świat, ale przemienia też niewolnika.

Wystarczy wyzwolić samego siebie, uzyskując uznanie ze strony Pana, aby znaleźć się w sytuacji prawdziwego - tzn. wzajemnego - uznawania. Egzystencja Pana jest „usprawiedliwiona” jako czynnik przeobrażający - przez Walkę świadome zwierzęta w Niewolników, którzy staną się pewnego dnia wolnymi ludźmi ${ }^{36}$.

Alexandre'a Kojève'a Wstęp do wyktadów o Heglu pokazał Józefowi Tischnerowi ważny trop w interpretacji myśli niemieckiego idealisty. Trop ten prowadził zarazem do uznania dialektyki i odrzucenia przemocy. Czytając i komentując wraz ze swoimi studentami teksty Kojève'a, Tischner musiał utwierdzać się w przekonaniu, że dochodzenie do wolności i pojednania między panami i niewolnikami nie musi dokonywać się przez cierpienie. Czas, w którym Tischner zajmował się tą kwestią, był szczególny - zima na początku 1982 roku, bezpośrednio po wprowadzeniu stanu wojennego w Polsce. Panowie, reprezentujący najwyższe władze partyjne, nie mogąc uzyskać uznania od niewolników pracujących na ich rzecz, wyprowadzili na ulice czołgi, aby zmusić tych drugich do uległości. Ale z jakiego powodu panowie nie mogli uzyskać tego uznania? Tischner, podobnie jak większość polskiego społeczeństwa, zdawał sobie sprawę, że powodem był brak chleba - panowie nie mieli nic do zaoferowania niewolnikom. Podczas gdy niewolnicy trudzili się w pocie czoła, aby dostarczać panom oczekiwanych

\footnotetext{
34 Tamże.

35 Tamże, 86-87.

36 Tamże, 87-88.
} 
dóbr i usług, panowie nie potrafili wypełnić wobec niewolników własnych zobowiązań. Skąd wzięła się ta niemoc? Kojève powtarzał, że wraz z wykonywaną przez niewolników pracą poprawia się sytuacja wszystkich. Co więcej, napięcia między tymi dwiema grupami słabną i ostatecznie znikają. W ich miejsce pojawia się wzajemne uznanie i pojednanie. Dlaczego takiego uznania i pojednania zabrakło w polskich warunkach? Powodem był upadek etosu pracy, odpowiadał Józef Tischner. Uspołecznienie pracy przez marksistów stało się jednocześnie uspołecznieniem robotników. To doprowadziło do odebrania im autonomii i do ich całkowitego uzależnienia od komunistycznej władzy. Uzależniając w taki sposób od siebie robotników, władza wzięła na swoje barki całkowitą odpowiedzialność za dostarczanie robotnikom chleba. Tego chleba jednak zabrakło i nic nie wskazywało na to, by pojawiło się go więcej. Dla Tischnera było więc oczywiste, że podstawowym obowiązkiem ciążącym zarówno na panach, jak i niewolnikach jest praca nad pracą. Tylko w ten sposób będzie można pokojowo przezwyciężać nieuniknione napięcia między panami i niewolnikami. Tylko tak będzie mogła ziścić się wizja Kojève'a i zdoła się uniknąć marksistowskiego fatalizmu dialektycznej przemocy. W 1989 roku Tischner pisał:

Czeka nas krok decydujący: przemiana pracy pozornej w autentyczną. Jeśli wszystkie dotychczasowe przemiany - przejście od monologu do dialogu i od dialogu do społeczeństwa osób - otworzą drogę do radykalnego wyjścia z iluzji pracy, to znaczy, że ich cel został osiągnięty. Jeśli do tego nie doprowadzą, czeka nas powrót do totalitaryzmu ${ }^{37}$.

W świetle tego, co powiedziano, łatwiej jest zrozumieć pojawienie się po 1989 roku wątku homo sovieticus w antropologii i filozofii społecznej Józefa Tischnera. Wątek ten jest zaskakujący w całym dorobku krakowskiego filozofa, gdyż ujawnia się w nim obca z gruntu dla Tischnera postawa wyższości i braku miłosierdzia dla ogromnej rzeszy ludzi, którzy nie potrafili dać sobie rady z sytuacją ekonomiczną po upadku komunizmu. W pewnym sensie Tischner był bardziej wyrozumiały dla przywódców komunistycznych w 1980 roku niż dla robotników 10 lat później. Tych pierwszych nazywał „braćmi-przeciwnikami”, natomiast o tych drugich tak pisał w tekście Homo Sovieticus między Wawelem a Jasną Górą: „Homo sovieticus odkrywa w sobie drugie dno: tego, czego wczoraj oczekiwał od komunistów i za co ich

37 Tischner, Etyka solidarności, 159. 
popierał, dziś oczekuje od «kapitalistów». Jest nadal mistrzem używania"38. Zarówno te gorzkie słowa, jak i inne wypowiedzi Tischnera z tamtego okresu wskazują na jego głębokie rozczarowanie rozwojem sytuacji społecznej i politycznej po podpisaniu umów Okrągłego Stołu. Kiedy Tischner pisał, że „[k]omunizm wszedł w człowieka głębiej niż przypuszczaliśmy” 39 , miał na myśli niezdolność wczorajszych niewolników do podjęcia twórczej i efektywnej pracy, która wiodłaby wprost do ich ostatecznego wyzwolenia, zgodnie z przewidywaniami Alexandre'a Kojève'a. Podczas gdy upadek komunizmu otwierał drogę do ostatecznego pojednania niedawnych panów i niewolników, do pokojowego zrealizowania wizji heglowskiej historiozofii, robotnicy, a także jak się okazało, wielu intelektualistów, było niezdolnych do wzniesienia się ponad historyczne nawyki i urazy, przedkładając celebrowanie niewoli ponad afirmację wolności. Tak przynajmniej tę sytuację oceniał Tischner. Czyniąc to jednak, stawał się raczej stroną w politycznym konflikcie niż bezstronnym komentatorem dziejów ${ }^{40}$.

Interpretacja heglowskiej filozofii historii przez Alexandre'a Kojève'a i kolejne jej analizy podejmowane przez amerykańskich konserwatywnych filozofów polityki, otwierają interesujące zagadnienie pedagogiczne, a mianowicie to, jaka filozofia edukacji byłaby najbardziej odpowiednia dla takiego właśnie podejścia do kwestii uznania niewolników. Przykładem takiej filozofii jest koncepcja edukacji modernistycznej zaproponowana przez współczesnego amerykańskiego myśliciela Stephena Hicksa ${ }^{41}$. Hicks wyróżnia trzy kluczowe okresy w rozwoju filozofii edukacji: okres premodernistyczny, w którym niepodzielnie dominowała edukacja religijna; okres modernistyczny, który wyłonił się z brytyjskiego oświecenia i odwołując się do rozumności i przedsiębiorczości jednostki, zaproponował model edukacji naukowej, nastawionej na postęp technologiczny; oraz okres postmodernistyczny, którego idee, czy to dotyczące kultury w ogólności, czy to edukacji w szczególności, stanowią intelektualne wyzwanie dla dwóch pierwszych modeli edukacji. Spośród trzech wymienionych filozofii edukacji najbliż-

38 Tamże, 188.

39 Tamże, 197.

40 Tischnerowska koncepcja homo sovieticus okazała się trwała w polskiej humanistyce i naukach społecznych. Odwołanie do niej znajdujemy np. w podręczniku Pedagogika ogólna [Por. Teresa Hejnicka-Bezwińska, Pedagogika ogólna (Warszawa: Wydawnictwa Akademickie i Profesjonalne, 2008), 195-196].

${ }^{41}$ Stephen Hicks, Zrozumieć postmodernizm. Sceptycyzm i socjalizm od Rousseau do Foucaulta, tłum. Piotr Kostyło, Katarzyna Nowak (Bydgoszcz: Wydawnictwo Uniwersytetu Kazimierza Wielkiego, 2016). 
szą koncepcji Alexandre'a Kojève'a jest koncepcja modernistyczna. Jest ona oparta na zasadzie „win-win”, to znaczy w miejsce walki i konfliktu między jednostkami wprowadza kategorię wzajemnych korzyści. Nawet jeśli członków społeczeństwa można by podzielić na panów i niewolników, to relacje między nimi nie muszą prowadzić do rewolucji. Przeciwnie, im dłużej panowie i niewolnicy żyją obok siebie, tym wyraźniej widzą, że o wiele więcej zyskują przez współpracę niż przez walkę. Współpraca ta staje się ostatecznie fundamentem społeczeństwa liberalno-demokratycznego. Natomiast gwarancją cywilizacyjnego sukcesu tego społeczeństwa pozostaje indywidualna przedsiębiorczość.

Czy Józef Tischner mógł uznać taką filozofię edukacji za swoją? Wydaje się, że pod wieloma względami byłaby mu bliska. Przede wszystkim polski filozof doceniłby w niej rangę indywidualnej wolności i odpowiedzialności człowieka. Takiej wolności oczekiwał po 1989 roku od wczorajszych niewolników w Polsce. Jednakże pewnym problemem dla krakowskiego myśliciela mogłaby być areligijność tej filozofii. Przyswajając sobie wartości społeczeństwa kapitalistycznego, jednostki nie potrzebują już żadnych odwołań do religii, twierdzi Stephen Hicks. Podczas gdy edukacja religijna podkreśla, że ,, [z] moralnego punktu widzenia człowiek jest zły i grzeszny”42, edukacja liberalna kładzie akcent na to, że „człowiek jest niezapisaną kartą"43, a to, jaki się stanie, zależy w pełni od niego.

\section{Wyzwolenie poprzez solidarność}

W tekstach Józefa Tischnera pojawia się trzeci trop odniesień do Hegla, najbliższy krakowskiemu myślicielowi. Trop ten ujawnia trzeci kontekst wyzwolenia, o którym można mówić przy okazji analiz Fenomenologii ducha i innych tekstów Hegla. Chodzi tu o wyzwolenie poprzez solidarność, rozumianą jako chrześcijańska cnota ${ }^{44}$. Wprowadzając tę kategorię do swojej an-

42 Tamże, 261.

43 Tamże.

${ }^{44}$ Słowo „cnota” nie jest tu być może najlepszym z możliwych. Kieruje nas bowiem do etyki będącej syntezą postaw ewangelicznych oraz racjonalności arystotelesowskiej. Jesteśmy w ten sposób sytuowani w tradycji chrześcijańskiej, z którą Józef Tischner toczył permanentny spór - w tomizmie. Kiedy krakowski filozof mówi o solidarności jako drodze do wolności, czyli do uznania niewolników, wydaje się bliższy tradycji mistycznej niż racjonalistycznej. Solidarność w jego ujęciu jest z pewnością bliższa miłosierdziu niż sprawiedliwości. 
tropologii i filozofii społecznej, Tischner nie tylko ujawnił swój światopogląd (co nie było niczym zaskakującym, biorąc pod uwagę, że był duchownym katolickim), ale także wskazał, że ostateczne przezwyciężenie konfliktu między panami i niewolnikami możliwe jest tylko na gruncie religijnym. Wymaga ono nie tylko rozumu, jak chciał Hegel, ale także wiary. Karol Marks głosił, że dialektyczne napięcia między burżuazją a robotnikami mogą być zniesione tylko w drodze rewolucyjnej przemocy. Tischner odpowiadał na to, że pomimo stosowania permanentnej przemocy przez rewolucjonistów, żadnych napięć nie udało się znieść. Przeciwnie, pogłębiały się one, a wizja ciągłej obecności czołgów na ulicach polskich miast stawała się coraz bardziej realna. Z kolei Alexandre Kojève twierdził, że do przezwyciężenia konfliktów, o których tu mowa, konieczna jest efektywna praca niewolników i uświadomienie sobie przez panów, że dzięki tej pracy oni sami mogą żyć. To doprowadzi do pojednania i wzajemnego uznania jednych przez drugich. Jak widzieliśmy, stanowisko to było bliskie Józefowi Tischnerowi. Dlaczego więc nie poprzestał on na propozycji Kojève'a i nie skupił swoich wysiłków w obszarze zaangażowań społecznych na ,pracy nad pracą”? Z jakiego powodu zwrócił się w stronę religijnie rozumianej solidarności, szukając także w niej odpowiedzi na pytanie o drogi dochodzenia do wolności?

$\mathrm{Ci}$, którzy chcieliby odpowiedzieć na to pytanie, odnosząc się do faktu, iż Józef Tischner był duchownym, mieliby w jakimś stopniu rację. Wchodząc w nurt filozofii kontynentalnej, zainicjowanej przez Georga W. F. Hegla, Tischner zdawał sobie sprawę, że odróżnienie w tym nurcie kwestii filozoficznych od kwestii światopoglądowych jest zazwyczaj bardzo trudne ${ }^{45}$. Nie wydaje się zresztą, by krakowski filozof starał się to robić. Nie oznacza to jednak, że przywoływał religijne interpretacje w każdym swoim filozoficznym tekście. Musiał być zatem inny powód. Być może chodziło o to, że ani interpretacje Marksa, ani Kojève'a nie miały odniesień religijnych. Wiara religijna nie miała dla żadnego z tych myślicieli znaczenia w wyjaśnianiu obiektywnych w ich przekonaniu procesów, na które wcześniej zwrócił uwagę Hegel. Być może w dyskusji z marksistami na temat dochodzenia do

${ }^{45}$ Kwestia zachodzenia na siebie światopoglądu i uprawianej filozofii jest często przytaczana jako zarzut pod adresem filozofii kontynentalnej [Por. Józef Bocheński, „O filozofii analitycznej”, w: Józef Bocheński, Logika i filozofia (Warszawa: Wydawnictwo Naukowe PWN, 1993), 35-49; Arno Anzenbacher, Wprowadzenie do filozofii, thum. Juliusz Zychowicz (Kraków: UNUM - Wydawnictwo Polskiego Towarzystwa Teologicznego, 1993), 29-39]. Interesujące jest, że Arno Anzenbacher był doktorantem Józefa Bocheńskiego, natomiast wstęp do jego książki napisał Józef Tischner. 
wolności i pojednania argumenty religijne były faktycznie pomocne Tischnerowi, ale dlaczego odwołał się do nich, komentując, w sposób jednoznacznie przychylny, interpretację zaproponowaną przez Kojève'a?

Odpowiedź na to pytanie przynosi najpierw chronologia. Teksty, które weszły w skład Etyki solidarności, zostały w większości napisane lub wygłoszone w okresie pierwszej Solidarności, przed wprowadzeniem stanu wojennego. Natomiast zwrócenie się w stronę interpretacji Hegla zaproponowanej przez Kojève'a nastąpiło bezpośrednio po zdruzgotaniu przez marksistów ruchu Solidarności. Chronologia nie tłumaczy jednak wszystkiego. Wydaje się, że Tischner, zajmując się zagadnieniem zniewolenia i wolności, był zainteresowany przede wszystkim takim jego rozstrzygnięciem, które miałoby charakter ostateczny. Nadzieję na takie ostateczne rozstrzygnięcie widział raczej w chrześcijańskiej etyce niż idealistycznej filozofii historii. Miał wątpliwości, czy obietnica samego Hegla będzie mogła zostać kiedykolwiek spełniona w drodze znoszenia przeciwieństw przez rozum. Hegel zapowiadał w swoich pracach ostateczne pojednanie wolności i rozumności, wzajemne uznanie wszystkich przez wszystkich i doskonałą jedność. Tischner, rozważając ponad 150 lat historii, które upłynęły w Europie od heglowskich zapowiedzi, nie ufał im bezwarunkowo. Wciąż szukał gwarancji, która da mu pewność, że oczekiwane pojednanie okaże się trwałe. Gwarancję taką znalazł nie w obiektywnym rozumie, ale w subiektywnej wierze. Uważał, że aby dzieje mogły się wypełnić, muszą mieć sankcję osobowego Boga.

Religijna interpretacja myśli Hegla nie była czymś zaskakującym. Sam Hegel w Wykładach z filozofii dziejów zachęcał do niej. Pisał tam:

Otóż poznanie, do którego [...] prowadzić ma filozofia, głosi, że świat rzeczywisty jest taki, jakim być powinien, że prawdziwe dobro, powszechny rozum boski posiada również moc urzeczywistniania siebie samego. Tym dobrem, tym rozumem w jego najbardziej konkretnym wyobrażeniu jest Bóg. Bóg rządzi światem, a treścią jego rządów, wykonaniem jego planu są dzieje powszechne ${ }^{46}$.

Zachęta Hegla sprawiła, że również inne pojęcia właściwe dla jego idealistycznej filozofii były postrzegane przez pryzmat doktryny chrześcijańskiej. W ten sposób interpretowano Ducha Absolutnego - jako rzeczywistość, pod którą kryje się Duch Święty; lub dialektykę poznawania siebie za pomocą

${ }^{46}$ Georg W. F. Hegel, Wykłady z filozofii dziejów, tłum. Janusz Grabowski, Adam Landman (Warszawa: Wydawnictwo Naukowe PWN, 1958), 54-55. Cytat ten w rozszerzonej postaci znajduje się we wstępie napisanym przez Tischnera do Spowiedzi rewolucjonisty [s. 6-7]. 
pojęć tezy, antytezy i syntezy - jako proces wzajemnego poznawania Ojca i Syna, prowadzący do wyłonienia się Ducha w Trójcy Świętej. Józef Tischner konsekwentnie podążał tym nurtem analiz tekstów Hegla, nadając im wszakże charakter bardziej etyczny niż dogmatyczny. Prowadziło to niekiedy do paradoksów, jak w przypadku tytułu książki Spowiedź rewolucjonisty.

Książką, w której Tischner zajął się wprost kwestią wyzwolenia poprzez solidarność, była Etyka solidarności $i^{47}$. O historii powstawania tej książki napisano już wiele, więc tę sprawę pozostawiam na marginesie. Krakowski filozof porusza $\mathrm{w}$ tej pracy zagadnienie zarówno wyzwolenia poprzez rewolucję, jak i wyzwolenia poprzez pracę. Każdy z tych tropów jest rozwijany w kilku krótkich rozdziałach, w których autor przedkłada tezy, o których była już mowa w niniejszym artykule. Tytuł całości wskazuje jednak na solidarność. Czym ona była dla Tischnera? Miała ona dla niego sens wyraźnie religijny.

Gdyby trzeba było jakoś bliżej określić znaczenie słowa „solidarność”, to należałoby chyba sięgnąć do Ewangelii i tam szukać jego rodowodu. Sens tego słowa określa Chrystus: „Jeden drugiego ciężary noście, a tak wypełnicie prawo Boże". Cóż znaczy być solidarnym? Znaczy nieść ciężar drugiego człowieka. Nikt nie jest samotną wyspą. Jesteśmy zespoleni nawet wtedy, gdy tego nie wiemy ${ }^{48}$.

Cytat ten jest fragmentem kazania, zatytułowanego przez Tischnera „Solidarność sumień”. W kolejnym tekście, pod tytułem „Wspólnota”, autor przywołuje i komentuje fragment Ewangelii, w którym jest mowa o miłosiernym Samarytaninie. $Z$ całości wyłania się wezwanie do solidarności przede wszystkim z ludźmi, którzy zostali skrzywdzeni przez innych. Zainteresowanie się ich losem i ulżenie ich cierpieniom - to rzeczy najbardziej godne człowieka. Można jednak słusznie zapytać, w jaki sposób tego rodzaju solidarność prowadzi do wyzwolenia niewolników spod władzy panów? Tischner wprost wzywa do solidarności z innymi ofiarami panów, nie z samymi panami. Na czym zresztą miałaby polegać w 1980 roku solidarność polskich robotników z kierownictwem partii marksistowskiej? Z pewnością nie na tym samym, co solidarność z innymi skrzywdzonymi robotnikami. Warto zatrzymać się w tym punkcie. Wojciech Bonowicz w tekście opublikowanym w Tygodniku Powszechnym pod tytułem „Czas nowej wspólnoty” w sposób nad wyraz cel-

\footnotetext{
47 Tischner, Etyka solidarności.

48 Tamże, 12.
} 
ny przedstawia główne wątki rozwijane przez Tischnera w Etyce solidarno-

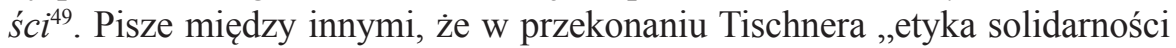
obejmuje każdego, kto «zechce mieć sumienie»" ${ }^{50}$. Wypowiadając te słowa, Tischner zwracał się do kierownictwa partii komunistycznej z apelem o pojednanie i wzajemne uznanie, bazujące na przebaczeniu i miłości bliźniego. Tylko taka droga dojścia do przezwyciężenia konfliktów między panami i niewolnikami mogła zagwarantować, według krakowskiego myśliciela, trwałość pojednania. Komuniści wykazali się jednak głupotą i odrzucili tę propozycję, nie chcieli lub nie potrafili odrodzić swoich sumień. Tak należałoby zinterpretować takie działania ówczesnej władzy, które miały na celu manipulowanie, prowokowanie i inwigilowanie ruchu Solidarności. Czyniąc to, komuniści pokazali, że są całkowicie pozbawieni kompetencji etycznych. Józef Tischner ufał, że po upadku komunizmu dawni niewolnicy nie zejdą $\mathrm{z}$ drogi etyki.

Po pożegnaniu z komunizmem człowiek wita się z samym sobą. Uświadamia sobie swą wolność. Wybiera ją jako podstawową wartość, od której może zacząć się etyka. Najpierw jest to etyka prawdy, człowiek staje się podmiotem prawdy. Następnie staje się własnością siebie. Od tego momentu jest podmiotem praw i obowiązków. Jako podmiot praw i obowiązków - jest odpowiedzialny za siebie. Nie jest niewolnikiem. Dopiero teraz może zdecydować, komu będzie służył, ale już nie jako niewolnik, lecz jako wolny ${ }^{51}$.

Tischner wyróżnił dwa rodzaje solidarności: solidarność zakotwiczoną oraz solidarność niezakotwiczoną. Pierwsza wyrasta na bazie więzi społecznych, które są najbliższe człowiekowi, które otaczają go od chwili jego narodzin. Jest to solidarność z rodziną i z narodem. Ma ona charakter naturalny i zazwyczaj nie wymaga od człowieka heroizmu. O takiej solidarności pisali między innymi tomiści, analizując kręgi ludzkiej miłości, oraz Henri Bergson, przedstawiając wizję tak zwanej moralności zamkniętej. Dla naszych rozważań ważniejszy jest jednak drugi rodzaj solidarności. Solidarność ta jest niezakotwiczona, gdyż nie wyrasta z naturalnych więzi, na których mogłaby się oprzeć. Jej charakter jest duchowy, obejmuje ona w istocie wszystkich ludzi, niezależnie od ich relacji do nas. Tischner uważał, że jesteśmy wezwani do solidarności z każdym, kto potrzebuje naszej pomocy, nieza-

\footnotetext{
49 Wojciech Bonowicz, „Czas nowej wspólnoty”, Tygodnik Powszechny 4.09.2005.

50 Tamże.

51 Tischner, Etyka solidarności, 171-172.
} 
leżnie od tego, czy go znamy, czy nie, czy jest naszym przyjacielem, czy wrogiem. Ten rodzaj solidarności z pewnością wymaga heroizmu. Postulat takiej solidarności wyłania się z chrześcijaństwa otwartego, o którym pisał wspomniany Henri Bergson. Ideę tę przejęli następnie francuscy personaliści, z Jacques'em Maritainem na czele i tą drogą dotarła ona do katolickich intelektualistów w Krakowie. Tischner, angażując się w życie społeczne w okresie pierwszej Solidarności, wzywał do praktykowania solidarności niezakotwiczonej. Ufał, że ówcześni niewolnicy będą w stanie wznieść się ponad swoje krzywdy i urazy, i pojednać się ze swoimi ciemiężcami. Do takiej postawy zachęcał także samych panów, nazywając ich na przykład „braćmi-przeciwnikami”, przypominając im, że oni także mają sumienia, które mogą obudzić. Wiemy, że te wezwania i zachęty nie przyniosły rezultatu. Nie doszło do wzajemnego uznania marksistowskiej władzy i społeczeństwa. Jedyny projekt, który w przekonaniu Tischnera dawał szansę na ostateczne przezwyciężenie konfliktu między dwiema grupami, nie został zrealizowany. Nadzieja Tischnera, że polska polityka w latach pierwszej Solidarności stanie się etyczna, okazała się płonna.

W koncepcji wyzwolenia poprzez solidarność było coś utopijnego. Tęsknota za stanem, w którym niewolnicy staną się solidarni z panami, a panowie z niewolnikami, może też wydawać się naiwna. Jak w ogóle można wychować jednych i drugich do podjęcia takiego wyzwania? Dotykamy tu przesłania ewangelicznego i jego paradoksu. Pisał o tym Henri Bergson.

Moralność Ewangelii jest w istocie moralnością duszy otwartej: czyż nie mielibyśmy racji, twierdząc, że Ewangelia, jeśli chodzi o jej najbardziej ścisłe nakazy, zakrawa na paradoks, a nawet na sprzeczność? Jeśli bogactwo jest złem, to czy nie wyrządzamy szkody ubogim, zrzekając się na ich rzecz tego, co posiadamy? Jeśli ten, kogo uderzono w twarz, nadstawia drugi policzek, czym staje się sprawiedliwość, bez której nie ma przecież miłosierdzia? Lecz paradoks upada, sprzeczność zanika, jeśli weźmie się pod uwagę intencję tych maksym, którą jest wzbudzenie pewnego stanu duszy. To nie dla biednych, ale dla własnego dobra, bogaty powinien porzucić swoje bogactwa ${ }^{52}$.

Przenosząc analizy Bergsona na poziom solidarności, należałoby powiedzieć, że niewolnicy powinni być solidarni z panami nie ze względu na pa-

${ }^{52}$ Henri Bergson, Dwa źródta moralności i religii, thum. Piotr Kostyło, Krzysztof Skorulski (Kraków: Znak, 1993), 63-64. 
nów, ale ze względu na siebie. Podobnie panowie - jeśli chodzi o solidarność z niewolnikami. Ten typ wychowania Bergson nazywa wychowaniem mistycznym ${ }^{53}$.

\section{Zakończenie}

Pytanie o wyzwolenie było kluczową kwestią podejmowaną w wielkiej debacie, jaka przetoczyła się przez Polskę w ostatnich dekadach XX wieku. Debata ta towarzyszyła ważnym wydarzeniom społecznym i politycznym, które dzisiaj zgodnie nazywamy drogą do naszej wolności. Józef Tischner został wciągnięty w wir tych wydarzeń, stał się nie tylko ich komentatorem, ale i aktywnym uczestnikiem. Językiem, do którego odwołał się wówczas krakowski filozof, był język Georga W. F. Hegla. Na początku XIX wieku Hegel, będąc świadkiem wydarzeń wstrząsających ówczesną Europą, zaproponował określoną historiozofię, która miała te wydarzenia wyjaśniać. Kluczowymi terminami dla tej historiozofii były „pan” i „niewolnik”, a także toczona między nimi „walka o uznanie”, która miała ostatecznie doprowadzić do „pojednania wolności i rozumności”. Podjęcie tej historiozofii przez Tischnera nie było czymś zaskakującym, niemniej wymagało od niego intelektualnej odwagi. Tischner wiedział, że wzbudzi to duży opór w kręgach konserwatywnych intelektualistów katolickich, zwłaszcza wśród duchownych, do których sam się zaliczał.

Kiedy Tischner zaczął analizować polskie problemy społeczne, niewolnikami była większość polskiego społeczeństwa, panami natomiast reprezentanci władzy komunistycznej. Był to okres szczególny, w którym system komunistyczny zaczął chylić się ku upadkowi. Na początku nie było to jednak oczywiste. W latach siedemdziesiątych nie stawiano sobie pytań o drogi całkowitego wyzwolenia spod władzy marksistów, zastanawiano się raczej nad sposobami sensownego współistnienia z nimi. To w tym okresie Józef Tischner zajął się kwestią polskiego kształtu dialogu i choć odnosił się sceptycznie do możliwości uczciwych rozmów z komunistami, to nie rezygnował z wezwań do szukania takich możliwości. Był to $\mathrm{z}$ pewnością wyraz jego myślenia personalistycznego, zakorzenionego w wartościach. W obszarze praktyki społecznej myślenie to przekładało się na postawę zaangażowania w bieżące wydarzenia w celu czynienia świata ludzkiego lepszym, tu

${ }^{53}$ Por. tamże, 100-104. 
i teraz, na tej ziemi. Już wówczas Tischner spotykał na swojej drodze ludzi cierpiących z powodu niewoli, niezgadzających się na nią. Ale jednocześnie ludzi zagubionych na drodze do wolności, niepewnych tego, kim są.

Powstanie pierwszej Solidarności i zryw społeczeństwa ku wolności w 1980 roku był dla Józefa Tischnera zaskoczeniem. Na jego oczach „działa się historia", nie tylko polska, ale i europejska, i globalna. Strajki w Gdańsku późnym latem 1980 roku zapowiadały zasadnicze zmiany w świecie. Podobnie jak marsz wojsk Napoleona przez Europę na początku XIX wieku. Szukając sposobów opisania tego, co się wówczas działo, Tischner zwrócił się spontanicznie do Ewangelii, która była mu najbliższa światopoglądowo, oraz do Hegla, który stał się jego filozoficznym przewodnikiem w całym tym okresie. W obu tych źródłach szukał odpowiedzi na pytanie, jak najlepiej opisać drogę do wolności, na którą weszli Polacy. Trzy przedstawione tu interpretacje tej drogi mają tę wspólną cechę, że związane są blisko z heglowską historiozofią. Wedle tej historiozofii konflikty między panami i niewolnikami, będące naturalnym stanem świata, zmierzają stopniowo i dialektycznie do ostatecznego rozstrzygnięcia. Jest to możliwe dzięki wzrostowi rozumności ludzi. W przekonaniu Hegla, jako jednostki i narody nie jesteśmy skazani na ciągłą walkę o uznanie. Tischner przyjął ten punkt widzenia, zdając sobie sprawę, że jest on pod pewnymi względami bliski religii chrześcijańskiej. Zaowocowało to podjęciem przez niego namysłu nad trzema koncepcjami wyzwolenia: poprzez rewolucję, poprzez pracę oraz poprzez solidarność. Trzecia koncepcja, odwołująca się wprost do etyki chrześcijańskiej, była oryginalnym wkładem Tischnera do toczonych dyskusji. Koncepcja ta jednocześnie okazała się najbardziej krucha w obliczu napięć społecznych w tamtym okresie. Wprowadzenie stanu wojennego w Polsce pod koniec 1981 roku było dla niej ogromnym ciosem.

Filozofia historii Georga W. H. Hegla jest pociągającym intelektualnie narzędziem wyjaśniania dziejów jednostek i narodów. Nie jest jednak narzędziem precyzyjnym. Widać to wyraźnie, gdy czyta się teksty Józefa Tischnera. Trudność ta jest powszechnie uważana za nieuniknioną przy próbach rozwijania niemieckiego idealizmu. Zdawał sobie z niej sprawę sam Tischner, wskazując, że pewne prace Hegla są łatwiejsze w lekturze, inne trudniejsze. Fenomenologia ducha, podstawowy tekst, na którym opierał się krakowski filozof w swoich analizach dochodzenia do wolności, należała według niego do tych drugich. Niemniej podążanie tropami Hegla było według Tischnera jedyną możliwością, aby w sposób w miarę zrozumiały opisać to, co działo się w Polsce w tamtym okresie. Ogromny odzew, z jakim spotkały się wówczas teksty i wystąpienia Tischnera w polskim społeczeństwie, a także 
ciągłe zainteresowanie dorobkiem krakowskiego myśliciela dzisiaj, świadczą o tym, że został on dobrze zrozumiany przez swoich współrodaków.

\section{Slaves on the Way to Recognition. Józef Tischner's Struggling with Historiosophy (Summary)}

In the eighties and nineties of the twentieth century Józef Tischner was a witness and participant of the political breakthrough in Poland. The breakthrough resulted in the fall of the communist regime and in regaining freedom by the society. Describing that process, Tischner regularly was referring to Georg W. F. Hegel's philosophy, and particularly to Hegel's analyses of the master and slave relationship. Before the breakthrough, in the Polish society communist leaders were masters, whereas workers were treated like slaves. In the article the author considers three ways of achieving recognition, that is freedom by slaves. Those ways had emerged from the Hegelian tradition and became reference points for Tischner. They were: liberation through revolution, liberation through work, and liberation through solidarity. Each way entailed serious historiosophical problems which Tischner had to face. The author analyses Tischner's struggling with the philosophy of history and indicates to its possible pedagogical references.

Keywords: slavery; freedom; revolution; work; solidarity; education.

\section{Niewolnicy na drodze do uznania. Józefa Tischnera zmagania $\mathrm{z}$ historiozofią (Streszczenie)}

W latach osiemdziesiątych i dziewięćdziesiątych XX wieku Józef Tischner był świadkiem i uczestnikiem przełomu politycznego w Polsce. Przełom ten doprowadził do upadku reżimu komunistycznego i odzyskania wolności przez społeczeństwo. Opisując ten proces, Tischner regularnie odwoływał się do filozofii Georga W. F. Hegla, a zwłaszcza do jego analiz relacji pana i niewolnika. Przed przełomem w polskim społeczeństwie panami byli przywódcy komunistyczni, natomiast robotnicy byli traktowani jak niewolnicy. W artykule autor rozważa trzy drogi dochodzenia niewolników do uznania, czyli do wolności, które wyłoniły się z tradycji heglowskiej i do których odwoływał się Józef Tischner. Były to: wyzwolenie poprzez rewolucję, wyzwolenie poprzez pracę oraz wyzwolenie poprzez solidarność. Każda 
z tych dróg wiązała się z poważnymi problemami historiozoficznymi, z którymi musiał się mierzyć Józef Tischner. Autor analizuje zmagania Tischnera z filozofią historii, wskazując jednocześnie na ich możliwe pedagogiczne odniesienia.

Slowa kluczowe: zniewolenia; wolność; rewolucja; praca; solidarność; edukacja.

\section{Bibliografia}

Anzenbacher, Arno. Wprowadzenie do filozofii, tłum. Juliusz Zychowicz. Kraków: UNUM - Wydawnictwo Polskiego Towarzystwa Teologicznego, 1993.

Bergson, Henri. Dwa źródta moralności i religii, tłum. Piotr Kostyło, Krzysztof Skorulski. Kraków: Znak, 1993.

Bocheński, Józef. Logika i filozofia. Warszawa: Wydawnictwo Naukowe PWN, 1993. Bonowicz, Wojciech. „Czas nowej wspólnoty”. Tygodnik Powszechny 4.09.2005. Bonowicz, Wojciech. Tischner. Kraków: Znak, 2001.

Freire, Paulo. Pedagogy of the Oppressed. New York-London: Continuum, 2005.

Fukuyama, Francis. Koniec historii, thum. Tomasz Bieroń, Marek Wichrowski. Poznań: Wydawnictwo Zysk i S-ka, 1992.

Hegel Georg W. F. Wykłady z filozofii dziejów, tłum. Janusz Grabowski, Adam Landman. Warszawa: Wydawnictwo Naukowe PWN, 1958.

Hejnicka-Bezwińska, Teresa. Pedagogika ogólna. Warszawa: Wydawnictwa Akademickie i Profesjonalne, 2008.

Hellman, John. „French 'Left-Catholics' and Communism in the Nineteen-Thirties”. Church History 12 (1976): 507-523.

Hicks, Stephen. Zrozumieć postmodernizm. Sceptycyzm i socjalizm od Rousseau do Foucaulta, tłum. Piotr Kostyło, Katarzyna Nowak. Bydgoszcz: Wydawnictwo Uniwersytetu Kazimierza Wielkiego, 2016.

Hyppolite, Jean. Genèse et Structure de la «Phénoménologie de l'Esprit» de Hegel. Paris: Aubier, 1946.

Kojève, Alexandre. Introduction to the Reading of Hegel. Lectures on the „Phenomenology of Spirit". Ithaca-London: Cornell University Press, 1969.

Kojève, Alexandre. Łaczny komentarz do pierwszych sześciu rozdziałów „,Fenomenologii ducha", tłum. Tadeusz Gadacz. Kraków: Wydział Filozofii PAT, 1982.

Kojève, Alexandre. Wstęp do wykładów o Heglu, tłum. Światosław F. Nowicki. Warszawa: Fundacja Aletheia, 1999.

Kostyło, Hanna. „Refleksja jako podstawa podmiotowości. Według antropologii Paula Freirego". Paedagogia Christiana 2 (2017): 157-170. 
Kostyło, Piotr. „Alain Badiou o współczesnej filozofii francuskiej”. Kronos 4 (2015): 87-98.

Krąpiec, Mieczysław A. Realizm ludzkiego poznania. Poznań: Pallottinum, 1959.

Kwiek, Marek. Dylematy tożsamości. Wokót autowizerunku filozofa w powojennej myśli francuskiej. Poznań: Wydawnictwo Naukowe Instytutu Filozofii UAM, 1999.

Marks, Karol. „Przyczynek do krytyki ekonomii politycznej”, thum. Edward Lipiński. https://maopd.files.wordpress.com/2012/02/przyczynek-do-krytyki-ekonomii-politycznej-1859.pdf [dostęp: 15.04.2018].

Olbrycht, Katarzyna. Prawda, dobro i piękno w wychowaniu człowieka jako osoby. Katowice: Wydawnictwo Uniwersytetu Śląskiego, 2000.

Pawlak, Zdzisław. „Rola religii w wychowaniu człowieka. Aspekt filozoficzno-teologiczny". W: Edukacyjny potencjał religii, red. Jerzy Bagrowicz, Jarosław Horowski, 105-119. Toruń: Wydawnictwo Naukowe UMK, 2012.

Przybyło, Sławomir. ,Wolność według Lorda Actona i Józefa Tischnera. Analiza porównawcza myśli dwóch katolickich liberałów". Politeia 11 (2014): 359-385.

Strauss, Leo. O tyranii: zawiera korespondencje Strauss-Kojève, red. Victor Gourevitch, Michael S. Roth, tłum. Paweł Armada, Arkadiusz Górnisiewicz. Kraków: Wydawnictwo Uniwersytetu Jagiellońskiego, 2009.

Tischner Józef, Spowiedź rewolucjonisty. Kraków: Znak, 1993.

Tischner, Józef. Etyka a historia. Wykłady. Kraków: Instytut Myśli Józefa Tischnera, 2008.

Tischner, Józef. Etyka solidarności. Homo sovieticus. Kraków: Znak, 2005.

Tischner, Józef. Filozofia współczesna. Kraków: Instytut Teologiczny Księży Misjonarzy, 1989.

Tischner, Józef. Polski kształt dialogu. Kraków: Znak, 2002.

Wajsprych, Danuta. Pedagogia agatologiczna. Studium hermeneutyczno-krytyczne projektu etycznego Józefa Tischnera. Toruń-Olsztyn: Wydawnictwo Naukowe UMK, 2011.

Weigel, George. Ostateczna rewolucja. Kościót sprzeciwu a upadek komunizmu, thum. Wojciech Buchner. Poznań: W Drodze, 1995.

Wood, Allen W. „Hegel on Education”. W: Philosophers on Education. New Historical Perspectives, red. Amélie O. Rorty, 300-317. London: Routledge, 1998.

Zdybicka, Zofia J. Religia w kulturze. Studium z filozofii religii. Lublin: Polskie Towarzystwo Tomasza z Akwinu, 2010. 
